\title{
КОРЕСПОНДЕНЦИЯ „НА СВОЙ ЯЗЫКЪ“: ЕЗИКОВИ ОСОБЕНОСТИ НА „КНИГА ЗА ПИСМА“ (1850) ОТ БРАТЯ КАРАМИНКОВИ
}

\author{
Надка Николова \\ CORRESPONDENCE ,IN YOUR OWN LANGUAGE“: \\ LINGUISTIC FEATURES OF „BOOK OF LETTERS“ (1850) BY \\ KARAMINKOVI BROTHERS \\ Nadka Nikolova
}

\begin{abstract}
The proposed text discusses part of the work of Stoyan and Hristo Karaminkovi „Диплография или какъ ся дрьжять търговскы книгы“" (1850), entitled ,Book of letters”. Karaminkovi's linguistic idiom is presented in detail. It is established that the language norms cannot be fully compared with the language norms in texts published before 1850, which were their models: Bogorov's grammar, the language of their teacher B. Petkov and the language of N. Gerov in „Conclusion from Physics“. The general idea of the written idiom of ,Book of Letters” is a deliberately sought symbiosis between tradition and spoken language, a conscious and smooth transition from linguistic antiquity to spoken language. All this is explained by the desire of Karaminkovi brothers to write for the general audience (,въвъ всеобщо употрьбленіе“), which phrase from the introductory part of "Diplography" is indicative of the meaning of the linguistic means - they are as they are in the usage of the majority of the language community.
\end{abstract}

Key words: book of letters, linguistic idiom, morphological means, tradition and spoken language

DOI: https://doi.org/10.46687/WKGA2453

Езикът на „Книга за писма““ - част от ръководството по двустранно счетоводство със заглавие „Диплография“, съчинено от Стоян и Христо Караминкови, - представлява интерес за историята на новобългарския книжовен език поради факта, че двамата братя не са известни книжовници, оставили имената си в изказвания за езика под формата на статии или бележки във възрожденската публицистика, нито в граматика, учебна литература, преводни или други творби. То е единственото им съчинение и освен него присъствието им в Българското възраждане се свързва изцяло със стопански инициативи и подкрепа на каузи, инициирани и поддържани от цариградските българи през 50-те - 70-те г. на 19. в. (вж. Nachov 1925: 13 и сл.; 1990: 216). Пишейки диплографията, те имат претенцията да дадат на българските търговци 


\section{Годишник на ФХН, XXXII A}

счетоводни и търговски умения „на свой языкъ“, за да принесат „колкогодъ ползицж на рода си“ - пишат те в увода $\left(8^{1}\right)$ на 15 февруари 1850 г.

Ст. и Хр. Караминкови, които са потомствени тьрговци ${ }^{2}$, макар и доста млади, когато пишат диплографията, едва ли са имали затруднения да ползват езика на търговията - гръцкия, преподаван почти във всяко училище из българските земи. Пък и солидната им училищна подготовка включва изучаването му. Двустранното счетоводство е известно в Южна Европа, вкл. и в Османската империя от столетия; литература под различна форма - в нарочни съчинения, в учебна литература и др. изобилства на гръцки език. Не бива да се забравя, че в активната билингвална среда, каквато е била тьрговската на Балканите, ползването на българския език не само в семейството, но и в съсловните социуми играе решаваща роля за съхраняване и предаване на родния език, осъзнаването на чиято символна роля в средата на 19. е повече от очевидна. Средата на 19. век е и времето, в което българският национализъм е в своя възход и това включва различни осъзнати актове, първостепенна роля от които има утвърждаването на българския език. Следователно създаването ${ }^{3}$ на такава литература на български език е акт, в който се провижда осъзнаването и осъществяването на някои от символните функции на езика - интегриращата и престижната.

Любопитство събужда декларацията им в увода: „Языкъ употрђбихме прость и вразумителенъ колкото бђше възможно...“ (9). Тя е напълно в духа на епохата, в която мнозина възрожденци афишират, че пишат на прост език (вж. подробно за понятието Del Agata 1983). Идеята за прост език има своята прогресивно-демократична същност, характерна за оформящата се буржоазна прослойка. Едва ли в представите на двамата ѝ представители черковнославянският език, носещ патината на

\footnotetext{
1 Числата в скоби отпращат към страницата. Всеки раздел в „Диплографія“ на Ст. и Хр. Караминкови, вкл. „Книга за писма“ (125-158), има собствена пагинация, започваща от c. 1. И тъй като образците за писма са разположени в два раздела (изпратени и получени писма) също със собствена пагинация, за удобство в настоящето изследване страницата се означава според фототипното издание, подготвено във връзка с честването на 150годишнината от издаването на тази първа книга по счетоводство в България по инициатива на проф. д-р Димитьр Спасов през 2000 г. Избраният начин на цитиране на страницата е съобразен също и с необходимостта от подкрепящи примери от други части на „Диплография“.

${ }^{2}$ Повече за семейството и образованието им вж. Nikolova (2019).

${ }^{3}$ Освен създаването, това включва и превода на български език на подобни съчинения, напр. превода на К. Мелас на „Търговско ръководство“ от Константинос Мелас (1858).
} 


\section{Надка Николова. Кореспонденция „на свой языкъ“...}

вече отминалото време, би бил подходящ за съдържанието на диплографията. Не би бил подходящ и за нейните прагматични читатели, които са стьпили здраво на земята и отправяйки си писма, пренасят обичайната си устна комуникация на белия лист, приготвен да пропьтува до търговски партньор, за който също като адресанта черковнославянският вече нито е „вразумителен“, нито престижен. Така предварителната нагласа за тълкуване на езиковите норми на произведението е да се види дали и доколко („колкото бъше възможно“) говоримият език е станал основната му тъкан.

Още една е причината да се смята, че езикът на писмата образци не е маловажен детайл от възрожденската книжовна дейност. Готовите епистоларни форми, които са на брой 53, имат за теми разнообразни търговски интеракции и са предназначени за отбран, но не и малоброен кръг ползватели. Доказателство за ползването им са не само многото спомоществователи и данните, че съчинението се е използвало и като учебна литература (по-подр. вж. Nikolova 2019; 2021). Достигналите до нас две писма от Евлоги и Христо Георгиеви, изпратени до Христо Караминков години по-късно (1867 и 1882 г.) (Kapralova 2013: 293-294), имат идентична постройка - като че ли само основното съдържание и имената са променени от някой от образците в „Книга за писма“. Разпространеността на писмата следователно би могла да допринесе за формиране на писмения език през последните десетилетия преди Освобождението.

Езиковите особености в „Книга за писма“4 се разглеждат по отношение на няколко лексико-граматични класа с оглед на морфологичните норми, като се отчита условността на писменото им означаване.

\section{СЬЩЕСТВИТЕЛНИ ИМЕНА}

Граматическите значения и формите за число, падеж и определеност/неопределеност при съществителните имена невинаги може да бъдат интерпретирани отделно, тъй като членните форми са в зависимост от числото и падежните облици на имената. Освен това - найвече при категориите род и число - тълкуването се извършва на принципа

\footnotetext{
${ }^{4}$ По същество този раздел е писмовник. Изследването е по проект № КП-06-Н40/8 на тема „Писмовниците на Българското възраждане като източник за формирането и функционирането на книжовния език”, финансиран от Фонд „Научни изследвания“ към Министерството на образованието и науката на РБ.
} 
на изключенията от съвременното състояние на съществителните имена. Обобщено формите на съществителните имена може да се представят в следната таблица.

\begin{tabular}{|c|c|c|c|c|}
\hline \multirow[t]{2}{*}{$\begin{array}{l}\text { Род и } \\
\text { число }\end{array}$} & \multicolumn{2}{|c|}{$\begin{array}{c}\text { Форми за именителен } \\
\text { падеж }\end{array}$} & \multicolumn{2}{|c|}{ Форми за косвен падеж } \\
\hline & $\begin{array}{c}\text { Нечленувани } \\
\text { форми }\end{array}$ & $\begin{array}{c}\text { Членувани } \\
\text { форми }\end{array}$ & $\begin{array}{c}\text { Нечленувани } \\
\text { форми }\end{array}$ & $\begin{array}{c}\text { Членувани } \\
\text { форми }\end{array}$ \\
\hline $\begin{array}{l}\text { М.p., } \\
\text { ед.ч. }\end{array}$ & $-\varnothing ;-a$ & $-m b$ & $\begin{array}{c}\text {-Ø // Род.-вин. - } \\
\text { a/-я // Зват. -е/- } \\
ю \\
\end{array}$ & $-m b / /-a /-я$ \\
\hline $\begin{array}{l}\text { М.p., } \\
\text { Мн.ч. }\end{array}$ & $-e ;-о в е ;-b l /-u$ & $-m b l /-m u$ & $-e ;-о в e ;-b l /-u$ & $-m b l$ \\
\hline $\begin{array}{c}\text { Ж.р., } \\
\text { ед.ч }\end{array}$ & $-a /-я ;-\varnothing$ & $-m a$ & $-\pi /-L \pi$ & $-m_{\AA}$ \\
\hline $\begin{array}{l}\text { Ж.p., } \\
\text { мн.ч. }\end{array}$ & $-b l /-u$ & $-m b l$ & $-b l /-u$ & $-m b l$ \\
\hline $\begin{array}{c}\text { Ср.p., } \\
\text { ед.ч }\end{array}$ & $-O /-e /-я$ & $-m o$ & $-o /-e$ & $-m o$ \\
\hline $\begin{array}{l}\text { Cр.p., } \\
\text { мн.ч. }\end{array}$ & $-a /-я ;-m a$ & $-m a$ & $-a /-я ;-m a$ & $-m a$ \\
\hline
\end{tabular}

1. Формите за род не представят примери, които са различни от съвременното състояние на съществителните имена. Прави впечатление единствено личното име Параскева, което е за мъж - Г-не Параскева Теофанов (132). Формата с окончание - $a$ е била използвана и за мъже, и за жени: една от сестрите на Ст. и Хр. Караминкови е носела името Параскева; то се среща още три пъти в списъка със спомоществователи, което показва, че не е било рядкост. Фигурира и в книгописа на М. Стоянов - Параскева П. Константинович, преводач на библейски текст от 1850 г. (Stoyanov 1957: 219). Името в тази форма е регистрирано в речника на Ст. Илчев за 1860 г. в Ловеч и Търново (Ilchev 2012: 506).

\section{именителен падеж}

2. Нечленувани форми на сыществителните имена в

2.1. При съществителните имена от мъжски род не се наблюдават разлики в сравнение със съвременните форми за единствено иисло. Сред формите за множествено число при многосричните съществителни се открояват образуваните с окончание -е, напр. пріятеле (3), господаре (127), алтжне (134), другаре (159), кредиторе (128), 
Алтжне (134), доброжьлателе (138). Многократно се среща и формата братіе (134). Те се конкурират с другата група, образувани с ок. -u/-bl, напр. Дльжници (82), Білланци (117), Търговцьь (128), Гайтаны (131). Видно е, че двете окончания -e/-u, както и двете графични оформления на ок. $-\boldsymbol{u} /$-bl се намират в активна конкуренция без оглед на синтактичната позиция на последните две (евентуално именителен/косвен падеж). Интересна е формата господиновии (22) (срв. със съвременната господа), която отвежда към модела за множествено число на личните и собствените лични имена от рода на дядовци, чичовци, Асеновци и под.

Тъй като в търговските операции се борави с количества, в образците често се срещат и словосъчетания на числителни бройни имена или на неопределителни местоимения със съществителни от мъжки род за нелица. Така се засвидетелстват бройни форми, напр.: $40 m \mathrm{~b} x ъ$ едък $a^{5}$, 25 Мъха (127), 2 Санджка (127), 1616 топа Осмакъ ${ }^{6}$ (128), пръди нъколко дена (136), прђди шест мъсяияа (161). Бе намерена и една форма за обикновено множествено число в съчетанието въ 24 часове (171).

2.2. Множественото число на имената от жкенски род се образува с окончание -ыl/-и, напр.: стокы, окы, (126), абы (134), смъткы (140), пары (147), иъны (151); чясти, Мънителници (127), заповђ ди (134). Изборът на буквата се свързва с фонетични условия - ако съгласната пред окончанието е (бивша) мека, то се пише с $u$.

2.3. Формите на имената от среден род в единствено число се отличават от съвременните само по окончанието на няколко от тях, които са от стари п-основи - в ръководството те са записани с черковнославянския си облик с окончание -я: время (126), имя (141). Останалите имат окончания -о или -е, напр. количество (128), писмо (149); Сждилище (168), дрьзновеніе (127), щеніе (135). Формите на имената от среден род в множествено число не се различават от съвременните, напр. врђмена, дъла (126), срьдия, писма (138). Една форма прави изключение - жита вм. очакваната от сьвременна гледна точка жито, която в това значение е singularia tantum: По нaшbстраны ся намирать доста жита на угодны иъьны... (150). Навярно семантичното разпределение на двете форми не е съществувало в речта на Караминкови.

\footnotetext{
${ }^{5}$ Едекъ (тур.) - 'волска кожа, в която се е наливало обикновено животинска мазнина, която е служела като мярка за тегло - един едек тежал между 300 и 500 оки“ (Tsonchev 1929: 68, no Vekov 2015).

${ }^{6}$ Осмакъ - вид гайтан.
} 


\section{3. Нечленувани форми на съществителните имена в косвен падеж}

3.1. Имената от мъжки род за нелица имат една-единствена форма независимо от синтактичната си служба в единствено и в множествено число. Само съществителните за лица в единствено число имат родително-винителни форми, напр. оть Г-на Дима Ивановъ (14), срђщзо С. Киворка (151), по Пьрвана Кераджія (151). Спазването на тези форми обаче не е повсеместно, напр. въ Гемія-та на Кипитанъ С. Ивановъ (128). Винаги родително-винителни са формите на титлата господин: на заповђ ь-тж Г-на К. Моровеновъ (30), по Г-на П. Христовъ (131), на другаря ни Г-на Х. Николовъ (131). Звателната форма, поради спецификата на търговските писма, се среща безизключително в обръщенията в началото на писмата - напр. Г-не Петре Генковъ (126), Г-да Василе Младеновъ и съдр. (128), Г-не Александре Цвътковъ (137), Г-да Михале Павлевъ и съдр. (139). Характерна е също при обръщение и вътре в основната част на писмото, напр. спорядъ сговорь-ть ни господине (133), Знаете пріятелю... (139) ${ }^{7}$. Много рядко може да се срещне дателна форма - напр. освобождава человьку умъ-тъ (7).

3.2. Имената от жсенски род представят една по-различна картина. В единствено число се различават две форми - за именителен и за косвен падеж. За именителен падеж вокалното окончание ${ }^{8}$ е $-\boldsymbol{a} /$-я, напр. Ако Мънителница ся яви... (169), ... и по нькогажь печяла ся показва, а по $н$ Ђкогажь загуба (139). Косвеният падеж се изразява с окончанието -ж/ьк, напр. свободж, смъткк, мънителниия, Ккщиицк (127). Сравни също Тозъ чясъ прђстигня благополучно Гемія-та... (им.п.) с ...и испратете съ прьвж Геміьћ (вин.п.) (131).

3.3. Имената от среден род в единствено и в множествено число са с обща форма във всички синтактични служби.

\section{4. Членувани форми на съществителните имена}

По времето, когато Ст. и Хр. Караминкови пишат ръководството, въпросът за употребата на членни форми е почти решен от практиката. Те са кодифицирани и в граматиките, по които са се обучавали братята: първоначално на Неофит Рилски (вероятно) и след това на И. Богоров 9 .

\footnotetext{
7 Тъй като търговията през 19. век е било изключително мъжко занимание, имена и съответно звателни форми на жени не се срещат, вкл. в списъка със спомоществователи.

${ }^{8}$ Изключват се имената с нулево окончание (от стара і-основа).

9 За биографични подробности вж. Nikolova (2019).
} 
Членуваните имена се срещат винаги, когато синтактичните условия ги предполагат, напр. Прьгледахме смьткж-тћ оть оцьненіе-то на съдружескљ-тж ни Лой, коюк-то намьрихме несгрђиенж и увьрихме $\partial \mathrm{b} б љ-m_{ж} B u$ за 1/2 ни чясть за 32400. грош. Има колебания относно правописа им (слято, полуслято или разделно) ${ }^{10}$, но не и относно фонетичното им съдържание.

4.1. При имената от мъжки род членните форми за единствено

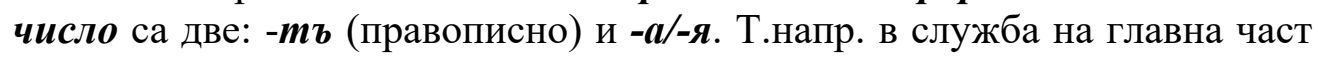
са формите бъльmъ-mъ (129), Пароплувъ-mъ (130) - въобще всички съществителни, изпълняващи служба на главна изреченска част, имат тази „пълна“ членна форма. Когато са в служба на второстепенни, настьпва колебание и се забелязва липса на определена система при избора на една от двете форми - Бакжра, бъльmъ-ть, навлжмь-ть, Кантаря (127), падежя (128), на Сапунъ-ть, оть Управителя на Пароплува (129), спорядь сговорь-ть (133), извънь обычяя (137), до пріятель-ть (153). От примерите е видно, че кратките членни форми на завършващите на (бивша) мека съгласна имена се записват с буква $я-$ тоест историческата мекост се запазва. Следователно следвана е устната форма на българската реч във вариантите, в които Караминкови я познават, без да се вземе решение кой от вариантите - пълният или краткият - да се използва и ако се използват и двата, как да се разпределят. Все пак забелязва се тенденция имената от мъжки род в служба на главни части на изречението да имат само пълна членна форма -mz; дори понякога се противопоставят на второстепенните (т.е. в косвен падеж) чрез членните форми, напр. Ако..., то е дльженъ запознавательтъ да докаже на пріятеля си... (166). В множествено число членната форма е -mbl/-mи: както за именителен падеж - напр. щуе зимать другарети (160), другаре-ты си зимать (164), циркуляри-ти навикнувать да ся печятани (165), така и за косвен, напр. на пріятеле-ты Bы (126), оть человъцыь-ты на Пароплува (129), да отдълять грошове-ты (146).

4.2. Отново при членуваните имена от женски род в единствено число има разграничение на именителен от косвен падеж, срв. напр. Тозъ чясъ прьстигнж благополучно Гемія-та съ Бакжра (131) с ...и ьк натварихъ на Гемікљ-тљ на Капит. Н. Какариновъ (150). В

\footnotetext{
${ }^{10}$ Вж. подр. в Nikolova (2021).
} 
множествено число членната форма е -mbl в именителен и в косвен падеж - стокьл-тьл, Tорбы-ты (129), Заповьди-ты (139).

4.3. Членуваните имена от среден род в единствено число имат една обща форма за всички синтактични служби - напр. слугуваніе-то (127), събраніе-то (131). Обща е формата и за множествено число, напр.: врьмена-та, дъла-та (126), поздравленія-та (156).

\section{ПРИЛАГАТЕЛНИ ИМЕНА}

Формите на прилагателните имена също се тълкуват съобразно синтактичната си служба, тоест в зависимост от падежа. Те се представят в следната таблица.

\begin{tabular}{|c|c|c|c|c|}
\hline \multirow[t]{2}{*}{$\begin{array}{l}\text { Род и } \\
\text { число }\end{array}$} & \multicolumn{2}{|c|}{$\begin{array}{c}\text { Форми за именителен } \\
\text { падеж }\end{array}$} & \multicolumn{2}{|c|}{ Форми за косвен падеж } \\
\hline & $\begin{array}{c}\text { Нечленувани } \\
\text { форми }\end{array}$ & $\begin{array}{c}\text { Членувани } \\
\text { форми }\end{array}$ & $\begin{array}{c}\text { Нечленувани } \\
\text { форми }\end{array}$ & $\begin{array}{c}\text { Членувани } \\
\text { форми }\end{array}$ \\
\hline $\begin{array}{l}\text { М.p., } \\
\text { ед.ч. }\end{array}$ & $\begin{array}{c}-\varnothing \\
-b l /-b l \check{u}\end{array}$ & $-i \check{u} /-b l u \check{u}$ & $\begin{array}{c}-\varnothing \\
-b l /-b l u ̈\end{array}$ & $-b i u ̈$ \\
\hline $\begin{array}{c}\text { Ж.р., } \\
\text { ед.ч }\end{array}$ & $-a$ & $-m a$ & - ж & $-m \pi$ \\
\hline $\begin{array}{c}\text { Ср.p., } \\
\text { ед.ч }\end{array}$ & $-O$ & $-m o$ & $-O$ & $-m a$ \\
\hline Мн.ч. & $-u$ & $-m u$ & $-b l$ & $-m b l$ \\
\hline
\end{tabular}

\section{1. Нечленувани форми на прилагателните имена}

1.1. Прилагателните имена в мъжки род в именителен падеж имат нулево окончание, напр. длъженъ е той (169) или Господарь-тъ на Мънителницж-тк е свободенъ (170). Образуваните със суфикс -ск- имена нерядко са с дълго окончание - Като ся намира Токатскый Бакжръ (132). Същото е положението и при формите за косвен падеж - напр. желаьк добърь успьхъ (146); да купуваме и продаваме Бакжрь съдружескы (145). Видно е, че дългото окончание е факултативно.

1.2. Подобно на съществителните имена от женски род, прилагателните в жсенски род разграничават форми за именителен и косвен падеж. За това свидетелстват примери като следните: за именителен падеж - Става неизбъжна нужда (161), Здрава Мънителница ся казва (169), Пріета Мънителница само съ думк быва нездрава, а законна и чинно подписана съ деня, е удобрена (169), Ако явена Мънителница ся загуби (171); за косвен падеж - За съдружескк смьткк (127), Съ гольмк благодарность (127), Ако намърите чистк и 
бълж Лой (126), Съ гольмж скърбъ (141). От примерите е видно, че причастията, функциониращи като прилагателни имена, се подчиняват на същите правила.

1.3. Формата за пряк и косвен падеж при прилагателните имена в среден род е обща, напр. Сговорно писмо ся казва (160), остава за вськога това сговорно и безсилно (163) (за пряк) и намьрихме го несгрђиено (135), Жђлаемь Ви добро здравіе (129), за крайно издльженіе (139) (за косвен падежс).

1.4. Има тенденция формите на нечленуваните прилагателни имена в множествено число да се разграничават по отношение на синтактичната си служба. В повечето случаи в именителен падежс окончанието се записва с буква $\boldsymbol{u}$, напр. то сте свободни (126), да останете благодарни (133), Останахме... мы съгласни (135), но и с буква b - Ако бъхк скъсаны (129), щуете да ны намирате готовы (148). В косвен окончанието винаги е ви, напр. Купихме Гайтаны Калоферскы (128), Пріехме Bашы двђ честны писма (128), какво гы натварихме здравы (129).

\section{2. Членувани форми на прилагателните имена}

2.1. Най-същественото при членуваните прилагателни имена от мъжкки род - както в пряк, така и в косвен падеж - е, че пълното старо окончание функционира като определителен член. Доказват го примерите: за именителен падежс - кога ся испълни общій влогъ (160), Прђстанова вече сегяшный ни подпись (141); за косвен падежс - за честный Ви отговорь (126), натварихме на Австрійскый Пароплувъ (127), подь долный знакь (128), чрезь рьченый пріятель (132), за скорый Ви отговоръ (132).

2.2. Отново подобно на членуваните съществителните имена от женски род, членуваните форми на прилагателните от жсенски род се разграничават падежно. Членната форма за именителен падеж е -та, напр.: Прьключена-та Ви Мьнителнница... ся пріе (131), като ся сключи годишна-та обща равносмьтка (163). Съответно член -тж е за косвен падежс, напр. Почетохте... малкљ-тж ни Кжичицћ (127), По турскљ-тж Почтж (129).

2.3. Членуваните прилагателни имена в среден род имат обща форма за всички синтактични служби. Това се доказва от следните примери: за именителен падежс-исто-то писмо ся получи (128), или ся подновява това сговорно писмо (161); за косвен падежс - Гледате околително-то ни писмо, което Ви изявява ново-съставено-то ни 
търговско съдружество (126), За рьчено-то количество (128), да сте пріели крайно-то ни писмо (131).

2.4. Членуваните сьществителни имена в множествено число се различават в пряк и косвен падеж. Членната форма за именителен падежк е -ти, напр. Както навикнувать друзи-ти пріятеле (133); $\mathrm{Mbl}$ подписани-ти... ся сговорихме (160); Да му го заплатять друзи-ти обрьщачи (170). Косвеният падежж се маркира с членна форма -mbl, напр. Съ прђключены-ты ни запознавателны двъ писма (126); на понуждныл-ты (126); на ръчены-ты господаре (127).

Прилагателните имена се степенуват така, както се степенува днес, напр.: за по гольля ясность (15), друго по-ново (153), най потрђбнж-тж книгж (2), най нуждна (13).

\section{ЧИСЛИТЕЛНИ ИМЕНА}

Формите на редните числителни имена, както и на бройното един, една и т.н. повтарят формите на прилагателните и по тази причина няма да се тълкуват. При бройните числителни имена по-особени са членуваните форми за множествено число като примера $c$ b $40 \mathrm{mb} \mathrm{bz}^{11}$ (130), от който се вижда, че числителното е в косвен падеж.

\section{МЕСТОИМЕНИЯ}

Местоименията, употребени в „Книга за писма“, представляват интерес в няколко аспекта. На първо място, въпроси извикват съставът, функциите и употребата на личните местоимения.

\begin{tabular}{|c|c|c|c|c|c|}
\hline \multirow{2}{*}{$\begin{array}{c}\text { Лице и } \\
\text { число }\end{array}$} & \multirow{2}{*}{$\begin{array}{c}\text { Имени- } \\
\text { телен } \\
\text { падеж } \\
\end{array}$} & \multicolumn{2}{|c|}{ Винителен падеж } & \multicolumn{2}{|c|}{ Дателен падеж } \\
\hline & & $\begin{array}{l}\text { Пьлни } \\
\text { форми }\end{array}$ & Кратки & $\begin{array}{l}\text { Пълни } \\
\text { форми }\end{array}$ & Кратки \\
\hline 1 л. ед.ч. & $a 3 b$ & $\begin{array}{l}\text { мень / } \\
\text { мене }\end{array}$ & мя & $-\varnothing$ & мu \\
\hline 2 л. ед.ч. & $-\varnothing$ & $-\varnothing$ & $-\varnothing$ & $-\varnothing$ & $-\varnothing$ \\
\hline $\begin{array}{l}3 \text { м.р. } \\
\text { ед.ч. }\end{array}$ & moŭ & него & 20 & нему & мy \\
\hline $\begin{array}{l}3 \text { ж.p. } \\
\text { ед.ч. }\end{array}$ & $m я$ & нењ / нея & $L \hbar$ & $-\varnothing$ & $-\varnothing$ \\
\hline
\end{tabular}

\footnotetext{
11 За формите от този вид вж. подробно Galabov (1954).
} 
Надка Николова. Кореспонденция „на свой языкъ“...

\begin{tabular}{|c|c|c|c|c|c|}
\hline $\begin{array}{c}3 \text { ср.p. } \\
\text { ед.ч. }\end{array}$ & $-\varnothing$ & $-\varnothing$ & $-\varnothing$ & $-\varnothing$ & $-\varnothing$ \\
\hline 1 мн.ч. & $M b l$ & $\mathrm{Hacb}$ & $\mathrm{Hbl}$ & $-\varnothing$ & $H u$ \\
\hline 2 мн.ч. & $B b l$ & Bacb & $B b l$ & $-\varnothing$ & $B u$ \\
\hline 3 мн.ч. & $\begin{array}{l}\text { miu / } \\
\text { mblя }^{12}\end{array}$ & $\begin{array}{c}m \mathrm{~b} x \mathrm{~b} / \\
\text { нuxb }\end{array}$ & $2 b l$ & $m \mathrm{~b} M b$ & Имь \\
\hline
\end{tabular}

От именителните местоименията в текста липсват само второличните по обясними причини: авторите на писма използват задължително учтиви форми в множествено число. Освен това третоличните местоимения заместват изключително или лица, които не са конкретни, а примерни, или нелица, напр. единственото срещнато местоимение той (169) замества издателя (кой да е). Конкретните (макар и фиктивни лица) в писмата са назовани със словосъчетания от типа на Господство му или Негова милость. А тя замества дылба (26) и кассжmж (27) или лице от женски пол (кое да е), каквото се среща само веднъж ${ }^{13}$. От формите за множествено число впечатление прави третоличното тыл, като отново не се заместват лица, а (в случая) думата писма (166). Личното местоимение за 1 и 2 л. мн.ч. е мы (126) и вы (146), както у мнозина съвременници на Караминкови.

По отношение на винителните местоимения може да се каже, че отново липсват за 2 л., ед.ч. Има известна конкуренция между формите мень (150) и мене (172); нась (126) и вась (138) са без разлика от съвременните. Високочестотни са кратките местоимения, от които за 1 л., ед.ч. се записва от авторите с черковнославянското мя (151) - подобно на мнозина техни съвременници ${ }^{14}$. Местоименията за множествено число графично са отразени като ны (127), вы (152), гы (151). По-особеното с

\footnotetext{
12 Двете форми, доколкото се намериха примери, се разпределят по род: първата е за референти от м.р., втората - за референти от женски и среден. По подобен начин са записани личните местоимения в Богоровата граматика.

${ }^{13}$ Интересна отпратка за лице от женски пол има само на едно място в „Диплографията“: когато се обяснява какво е „здрава мънителница“ - издавана от „търговецъ, банкеринъ работникъ (сарафинъ) и просто свободенъ човък“. За разлика от нея „слаба мънителницж“ се издава от „священникъ, войскаринъ, слуга, невъзрастенъ и женж“. По изключение жената може да обнародва менителница, ако мъжът ѝ го няма и с негово позволение „тя управлява дъла-та му“.

14 Нито Неофитовата, нито Богоровата граматика внушават този вариант на енклитичните местоимения. Любопитно е да се сравни с правописа на учителя им Ботьо Петков, който използва черковнославянския вариант също.
} 


\section{Годишник на ФХH, XXXII $A$}

оглед на диалектното койне от Централния Балкан, към което принадлежат калоферците Караминкови, е срещнатото веднъж местоимение нuхъ (166) вм. многократно употребеното $m \mathrm{~b} x ъ(8,16,18)$. Падежното значение на винителното местоимение за ж.р. ед.ч. предполага етимологичното му записване - нељк (138) (понякога и нея) и њ (151). Местоименията за трето лице също заместват нелица или обобщено назовани лица, напр. исканіе-то... съ него (19); нђкой запознава пріятеля си с другъ пріятель, сир. или само да ся запознае просто съ него (166); Тратта... чрезъ нењ (167) или дневна-та книгж... оть нея (13).

Това, което е най-характерно за дателните местоимения за 3 л., е, че липсват пълни форми освен две - нему (167) и $m \mathrm{~b} м ъ$ (25) - отново не за конкретни лица. Обикнати са кратките дателни форми, които са високочестотни. Бе намерено еднократно дателно местоимение за 1 л., ед.ч. в необичайна синтактична позиция: Cпорядь сговоръ-ть ни, ми не е до толкова угодно (150) - срв. напр. с кољћ-то ми бьше пратиль (150). В коментирания пример или словоредът е обърнат (*не ми е угодно), или по-скоро дателното местоимение носи подчертан акцент, макар и да е в начална изреченска позиция (което е старинна черта). Очаквано третоличното му отново не е за конкретно лице: а третій да увъримь за оцьненіе-то на пратены-ты му стокы (16). Формите за 1 и 2 л., мн.ч. за отлика от винителните - редовно се записват с $и$ : да ни ся отговорите (152), да Ви забъльжимь (126).

На няколко пъти се забеляза, че лични местоимения се използват със значение на показателни - също характерно за източните говори: той остатъкъ ся прьнася (13); отъ него оцьненіе (127), въ него писмо (135). Употребата им не учудва, доколкото в граматиката на И. Богоров като показателни (,указателни“ в терминологията му) се представят местоименията той и онъ (Bogorov 1844/1986: 46). Въобще примерите от писмовника не убеждават в разграничаването на третоличното местоимение за мн.ч. от показателното местоимение за съществителни в мн.число.

Притежателните местоимения се срещат редовно, като изключим второличните в единствено число по същите причини (спазване на етикета).

\begin{tabular}{|c|c|c|c|}
\hline $\begin{array}{c}\text { Лице и } \\
\text { число }\end{array}$ & $\begin{array}{c}\text { Именителен падеж - } \\
\text { пьлни форми }\end{array}$ & $\begin{array}{c}\text { Косвен падеж - } \\
\text { пълни форми }\end{array}$ & Кратки \\
\hline 1 л. ед.ч. & $*_{\text {мой, }} *_{\text {моя }}$ & $*_{\text {мой, } \text { мою }}$ & ми \\
\hline
\end{tabular}


Надка Николова. Кореспонденция „на свой языкъ“...

\begin{tabular}{|c|c|c|c|}
\hline 2 л. ед.ч. & $\varnothing$ & $\varnothing$ & $\varnothing$ \\
\hline $\begin{array}{l}3 \text { л. м.р. } \\
\text { ед.ч. }\end{array}$ & *неговъ, негова & *неговъ, неговж & My \\
\hline $\begin{array}{c}3 \text { л. ж.р. } \\
\text { ед.ч. }\end{array}$ & *неинъ, нейна & *неинъ, & $\check{u}^{15}$ \\
\hline 1 Л. мн.Ч. & *нашь, нашя & *нашь, нашьк & Hu \\
\hline 2 Л. мн.ч. & вашь / *вашя & *ваши, вашцк & Bu \\
\hline 3 Л. МН.Ч. & $\begin{array}{c}*_{m \mathrm{~b}} \text { енъ, }{ }^{*} \text { тьхна } \\
*_{\text {нихенъ, }}{ }^{*} \text { нихна }\end{array}$ & 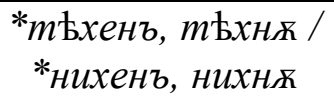 & uMb \\
\hline
\end{tabular}

Пвлните форми ${ }^{16}$ се членуват, когато това е необходимо, по същия начин както прилагателните имена. Това важи и за формите за 3 л., м.р., които са с пълно окончание, напр. за нашій народъ (7), испълни жђланіе-то ни Вашій честній отговорь (132). В сила е и при косвения падеж, където формите за женски род приемат окончание -ж, напр. мољк (150), неговж (150); намя-та смъса е $1 / 2$ чясть... то ть хнж-тж смъсж оть Оцъненіе-то ще да отдълите (127). Отново се среща конкуренция между две форми за 3 л., мн. ч. - $m$ ъхенъ и нихенъ, срв. предходния пример със следния: пріятеле... за Нихнк смьткк (29).

Както при личните местоимения в косвен падеж, и тук може да се твърди, че много по-честотни са кратките притежателни местоимения, чиито форма и употреба са както в съвременния български език, напр. дђлба-та ми (151), тегленіе-то му (149), стойность-тж й (153), въ Града ни (147), познайнство-то Ви (152), Господство имь (146).

Редовна е употребата на възвратните местоимения - лични и притежателни. Техният състав, формите и употребата им са както съвременните, напр.: за да оздрави себе си (170); безъ да има... свой человъкъ (171), да земк правдинж-тж си (150), да има въ дъла-та си (151).

Нищо от въпросителните и образуваните от тях неопределителни и отрицателни местоимения не е по-различно от съвременното им състояние. Единственото по-особено е употребата на

\footnotetext{
${ }^{15}$ Навсякъде това местоимение се отбелязва с буквата $\check{u}$.

16 Тъй като не винаги са намерени всички форми на нечленуваните и членуваните притежателни местоимения, в таблицата се предлага по намерените реконструираната форма за м.р. и за ж.р., ед.ч., означена с *.
} 


\section{Годишник на ФХH, XXXII A}

какво, което има и значението на съюза че, който се среща в ръководството единствено във формата ако би че (вж. условно наклонение по-долу).

Измежду неопределителните местоимения нерядко се срещат композитумите от рода на какъв да e (142) или едь кого си (168). Различават се именителни и косвени форми от типа на нькой (166) и нђкого (171). Интересни са правописните пропуски, издаващи произношението на наследника на ятовата гласна в представката - напр. нячто (126), но и некољк (130). Многолюдният Цариград, събрал българи от всички диалектни области, вероятно е предлагал и източното, и западното произношение на наследника на Ł, което вероятно е накарало авторите на „Диплография“ да смесват (дали нарочно или случайно) двоякия му изговор. Това обстоятелство може да обясни и западнобългарските форми нихъ и нихенъ.

По-специално място следва да се определи на относителните местоимения, тъй като те са особен прономинален клас в сравнение с останалите славянски езици, развили са се сравнително късно и имат специфична употреба. Функционирането им като съюзна дума в постпозитивни подчинени изречения (най-често определителни) е маркер за книжовна обработка в речта на възрожденските книжовници и винаги се е коментирало при определяне на нормите, които са характеризирали текстовете им. И тук може да се посочи, че Караминкови редовно ги употребяват. Нередовни са родителновинителните форми за мъжки род, ед.ч., напр. за смьткж на който ьк пращца (167) и др. По-отличителното при относителните местоимения за съществителни от м.р., ед.ч. е, че когото е форма за косвен падеж не само за референти лица, но и за нелица, при това редовно. Това се доказва от многобройни примери като день-тъ въ когото (14), Групъ... когото (129), подпись, подь когото (141), бьльть... съ силж-тж на когото (149) и мн.др. Диференциацията им като родително-винителната форма само за лица не е позната за Караминкови, както не е посочена и във възрожденските граматики ${ }^{17}$. Много рядко се среща и дателната форма за м.p. - комуто (132). Косвеният падеж при формите за женски род, ед.ч. е отразен в бившето окончание на въпросителното местоимение, станало

\footnotetext{
17 По този повод Б. Вълчев посочва, че във възрожденските граматики „изобщо не се прави никаква разлика между лица и нелица. Дори обратното, най-често те се срещат в комбинация с име за нелице“ (Valchev 2008: 457).
} 


\section{Надка Николова. Кореспонденция „на свой языкъ“...}

вътрешна морфема за относителното - напр. коя-то (148) и кољжто (126), коцћ-то (139).

Падежното разграничение в жсенски род, ед.ч. се наблюдава и при показателните местоимения, напр. докль да ся изяви и тая грђика (19) и да земе тжљк чясть в брой (170). В мъжкки род родително-винителните форми за лица се употребяват без колебание, напр. като задлъжимь прьво оногова (16), на оногова, който ьк издава (167). Отчетливо се разграничават показателни местоимения за близки от тези за далечни предмети и признаци, напр. тая (13), задлъжявать ся тіи (12), тыл (13), такљ-вљ (146), тжкћ (170) срещу оныя (13), оный (17), оногова (167), онова (166).

\section{ГЛАГОЛИ}

Най-същественото при глаголите, употребени в „Книга за писма“ (съответно в „Диплография“, от която писмовникът е част), има отношение към употребата на един или друг тип окончания за формите в сегашно време на глаголи от I и II спрежение. Всеки специалист в областта на стандартологията е наясно с използването на термина „окончание“ в този случай - става дума за характера на крайната съгласна от глаголната основа, която може да е твърда или мека, от една страна, и за писменото означаване на окончанието, което варира в диалектите. Най-разпространени в този период са окончанията, в които старата носовка е наследена от вокалите [ъ] или [a].

Глаголите от II и някои от I спрежение в 1 л., ед.ч. и 3 л., мн.ч. в сегашно време имат последователно мека основа, напр. само в едно писмо, писано от първо лице (с автор Параскева Теофанов) глаголите са следните: желањк, идж, правњк, наумњк, разносять, купять, испратять (145). Може да се обобщи, че глаголите в тези форми последователно са с меки окончания. От примерите е видно и че окончанието се записва последователно с ж/ьк, когато е в ед.ч., а в 3 л, мн.ч. - с -а/я. Въпросното разпределение едва ли има за цел обединение на два вида изговор, тъй като авторите не са изкушени филологически, никъде не се срещат други техни разсъждения за формиращата се нормативност или за правописа освен вече изтъкнатите. Може би е плод на колебание, отразено компромисно по този начин, още повече, че има и форми, записани с ж/ ж - напр. щжть земжть (162), а може да е и влияние от изговора на смесения в диалектно отношение узус на българите в Цариград.

Като се прибави и това, че никъде не се среща окончание -ме при глаголи от I и от II спрежение за 1 л., мн.ч. - напр. останемь, пимемь, 


\section{Годишник на ФХH, XXXII A}

направимь (145), - следва да се обобщи, че глаголната парадигма отговаря в най-висока степен на съвременната представа за глаголни форми в сегашно време, на съвременната норма. За формирането ѝ принос за утвърждаването имат и твърде разпространените през 30-те 70-те години писмовници, с чийто авторитет на универсален образец възрожденският българин несъмнено се е съобразявал.

Парадигмата за бъдеще време изглежда по следния начин (илюстрирана с различни глаголи):

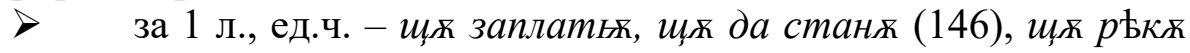
(153), щзљ да Ви расправњћ (147), щзљ да Ви явњк (151)

$>\quad$ > 2 л., ед.ч. - щеешь да проумеешь, щзешь срђщзешь (27)

> $\quad$ за 3 л., ед.ч. - щуе да положи (20), щуе ся побрька (126), щуе ся продаде (133)

> $\quad$ за 1 л., мн.ч. - щземь говоримь (21), щземь да осрђбримь, щемь да испратимь (130), щемь да осрђбримь (137), но и щуе съберемь, щуе ся ползуваме, щуе да испьлняваме (130); внимание заслужава формата със съкратен инфинитив щеем яви (138)

$>\quad$ за 2 л., мн.ч. - щете срђщунете (27), щуете да упжтите, щете да отдылите, щуете да пріемете (127), но и щзе изврьиите (130), щзе ни задльжите (132), щуе посрђщнете (153)

> $\quad$ за 3 л., мн.ч. - щзжть поканять (160), щзжть да ся съвьтувать, щкть да разсждять, щкть да подновять (161), щжть земжть (162), но и щзе ся разделять (159), щуе зимать, щзе ся давать.

Примерите показват, че братя Караминкови си служат със спрегаемия глагол щз, който е използван последователно само в 1 и 2 л., ед.ч., последван факултативно от частицата да и личната форма на глагола. Впрочем факултативното ѝ присъствие е в сила за всички форми. Във формите за мн.ч. щуе конкурира сериозно спрегаемия глагол щқ, замествайки го и преминавайки в класа на частиците. Тази конкуренция в един ,жив“ текст, за какъвто претендират писмата, илюстрира добре тенденцията за формалното унифициране на парадигмата в бъдеще време, характерен за централните балкански говори и отразен още в буквара на Петьр Берон. Отрицателните форми се образуват чрез поставяне на отрицателната частица не (записана разделно или слято с

\footnotetext{
18 Поради спазване на етикета в писмата тези два единствени примера са намерени във встъпителната част на „Диплография“ - „Какъ ся дрьжять търговскы книгы“, - в която авторите използват формите с обобщително значение (т.е. всяко едно лице).
} 


\section{Надка Николова. Кореспонденция „на свой языкъ“...}

глагола), напр. нещуе да го уплаши (9), нещуе да бжде (11), не щземь да прибъгнемь (133), не щете познаете (142), но и чрез по-новата форма с ньма - напр. нђма да продльжяваме (16).

В писмата се срещат форми и за други глаголни времена, когато това се изисква от съдържанието. Те също отговарят във висока степен на съвременната представа за формалното им представяне, напр. за аорист - умрь, разболь (16), натварихме, притекохте, почетохте (127); за имперфект (много рядко) - усъизахме (2); за перфект - е станжло (129), сме минжли (137), сме изкарвали, сме ся ползували (145), испратиль сьмь (151), сте направили (155); за бъдеще в миналото щзяхме да го пратимь (133), шяях да ся убавять (138). Не се намериха само форми за минало предварително и двете бъдещи предварителни времена вероятно просто защото съдържанието на писмата, а и на целия текст на съчинението не предполага употребата им.

Тъй като писмата имат назначението да предадат писмено отправено съобщение, разговор на прагматична тема, който освен това да е и документ ${ }^{19}$, в областта на глагола е любопитно дали има форми за преизказване. Малкото намерени убеждават, че то е жива категория, чиито значения и форми се използват без разлика от съвременните - а именно да препредават информация, да подчертават несвидетелския ѝ характер, напр. доста Бакжръ... както ся научяваме навђрно отъ единъ нашь пріятель, какво на добрл цьњк ся продаваль и ся трьсиль вь тыя дни (131-132), Гемія-та, въ коюк-то бђше натваренж съдружескж-тл ни Пченицж, потьнжла въ моря-то и съвсьмь ся изгубила, което извьстіе още минжлљ-тк недъльк пріехме (139).

Основното наклонение на писмата е изявителното, като повелителното и условното също имат своето място. От намерените повелителни форми по-старинна е виждь (129). Другите намерени имат съвременен вид: натварете (126), побрьзайте, знайте, явете (127), навьстете (131), бждете (148). Формата не отбьгновайте (130) вероятно е формирана от глагола *отбягновам, контаминирал от *отбягна и *отбягвам и двата суфикса (-н за свършен и -ова за несвършен), за да се трансформира така, че да образува отрицателен статус (*не отбягвайте). Условното наклонение, макар и рядко, има особени форми: ако бы че стане нужда, ако бы че купите (127), ако бы

\footnotetext{
19 Във въвеждащата част подробно се обяснява как да се събират, подреждат и съхраняват като писмена гаранция за интеракция.
} 


\section{Годишник на ФХH, XXXII A}

че намърите (130), ако бы че съберемь (138). Най-напред, следва да се посочи, че единствено в тези комплекси че присъства в писмата, проявявайки се обаче като частица (по-горе се посочи, че вместо съвременния съюз че се употребява какво). Трудно е да се определи как точно комплексът ако бы че е придобил условно значение, тьждествено на бих бил/-a, -о, -и. Несъмнено модусът на условността се носи от условния съюз ако, съчетан с неизменяемия глагол бы и подсилен с частицата/съюза че (който участва в редица съставни съюзи - макар че, въпреки че, освен че, като че, само че, при все че, тъй че). И тъй като кондиционалното значение се носи изцяло от ако бы че, към него остава да се добави в съответното лице и число глагольт, носител на лексикалното значение. Предполага се, че комплексът е типичен за централната балканска реч. Има и една форма, образувана с причастие: каква да бы была (9).

ИЗВОДИТЕ за характера на езика на братя Караминкови са в пряка връзка с обстоятелството, че учителят им Б. Петков, преподавайки по Богоровата граматика, утвърждава решението им съчинението да бъде написано на „прост“ и „вразумителен язик“ - на езика на ежедневната комуникация. Това обаче никак не е лесна работа поради ред причини. Една от тях е диалектното вариране, на което младите тьрговци, пребиваващи в пъстрия Цариград, са свидетели. От друга страна, намерението за изложение на прост език и представата им за него се е конфронтирало с търсенето на опора в етимологията, което е неизбежно, като в някои моменти едното или другото са вземали превес. Липсвали са и общоприети образци, тъй като приетите правила от един авторитетен източник (учител и граматика; влиятелно четиво) са били заменими от друг. Нерядко смяната на учител или училище - такъв е и този случай разколебават в следването на само един определен модел. Ето защо езиковите норми в „Книга за писма“ не може да бъдат сравнявани изцяло с езиковите норми в Богоровата граматика, с езика на Б. Петков (доколкото е възможно да бъде определен в кратичката му статия в Цариградски вестник от $1848 \Gamma^{20}$ ) и с езика на Н. Геров в „Извод от физика“ $(1849)^{21}$ - и трите публикувани до февруари 1850 г., когато е отпечатана „Диплография“.

${ }^{20}$ Вж. Petkov (1848).

${ }^{21}$ Има основания да се смята, че Христо Караминков е учил френски при Н. Геров, близък приятел на Б. Петков, а и реминисценции от увода в „Извод от физика““ в 
Би могло да се каже, че в езика на братя Караминкови в областта на морфологията почти не се срещат диалектни черти, характерни за централнобалканския говор, към който принадлежи Калофер, и останали вън от съвременната книжовна норма. Някои от тях, например варирането на членните форми, общата родително-винителна форма за имена на лица от м.р., ед.ч., нормативна до Втората световна война, глаголните окончания в сегашно време, постепенното избистряне на формите за бъдеще време с частица ще и др. характеризират формирането ѝ до края на 19. век. На места, по-скоро като изключения, се промъква например окончанието -ъ при съществителни от женски род в именителен падеж (бъ ше натваренљ съдружескљ-тк ни Пченииљ, 139) или специфичният начин за образуване на условни форми и др. потяснодиалектни особености. Всъщност, ако от съвременна позиция означим като диалектни някои черти, характерни за езика им, ще се окаже, че са минимални като присъствие. Стремежът към дистрибуция при означаване на окончания (напр. именителен и косвен падеж при имената и местоименията от/в ж.р., глаголите в сегашно време от 1 и 2 спрежение за 1 л., ед.ч. и 3 л., мн.ч. и др.), - както и правописът, при който се държи сметка за етимологията, внушават идеята, че в писмения идиом на „Книга за писма“ е търсена симбиоза между традицията и говоримата реч, че има осъзнат и плавен преход от езиковата старина към говоримия език - без декларации, без изтъкване. Всичко това се обяснява със стремежа на Караминкови да пишат това, което е „въвъ всеобщо употрђбленіе“ (3), която фраза от уводната част на „Диплография“ е за терминология, но е показателна за осмислянето на езиковите средства, с които смятат, че трябва да се пише - такива, каквито са в узуса на преобладаващата част от езиковата общност.

\section{ИЗПОЛЗВАНА ЛИТЕРАТУРА}

Bogorov 1844/1986: Bogorov, I. Parvichka balgarska gramatika. Fototipno izdanie.

Sofia: Nauka i izkustvo [Богоров, И. Първичка българска граматика. Фототипно издание. София: Наука и изкуство].

Del Agata 1983: Del Agata, Dzh. Belezhki varhu istoriyata na ezikovia vapros v Bulgaria. - V: I MKB. Istoricheski razvoy na balgarskia ezik. 1. Sofia: Izd. BAN, 92-98 [Дел Агата, Дж. Бележки върху историята на езиковия

уводната част на „Диплография“ водят до заключението, че би могло да е налице известно влияние върху младите автори. 


\section{Годишник на ФХН, XXXII A}

въпрос в България. - В: I МКБ. Исторически развой на българския език. 1. София: Изд. БАН, 92-98].

Galabov 1954: Galabov, Iv. Pet, pettyah, petima, petmina. - Balgarski ezik, № 3, 250258 [Гълъбов, Ив. Пет, петтях, петима, петмина. - Български език, № 3, 250-258].

Ilchev 2012: Ilchev, St. Rechnik na lichnite i familni imena u balgarite. Sofia: IztokZapad [Илчев, Ст. Речник на личните и фамилни имена у българите. София: Изток-Запад].

Kapralova 2013: Kapralova, N. I shte gospodaruva mazhat ti nad teb. Arhiv na Elisaveta i Hristo Karaminkovi. Sofia: AI Prof. Marin Drinov [Капралова, Н. И ще господарува мъжът ти над теб. Архив на Елисавета и Христо Караминкови. София: АИ Проф. Марин Дринов].

Nachov 1925: Nachov, N. Tsarigrada kato kulturena tsentara na balgaritb do 1977 godina. [Sofia] [Начов, Н. Цариградъ като културенъ центъръ на българить до 1977 година. [София].

Nikolova 2019: Nikolova, N. „Diplografiya ili kaka sya dryzhyaty targovskы knigы” (1850) ot bratya Karaminkovi - predvaritelni belezhki. - V: Rada i priyateli. Sbornik v chest na prof. d-r Radka Vlahova. Sofia: UI Sv. Kliment Ohridski, s. 275-284 [Николова, Н. „Диплографія или какъ ся дрьжять тьрговскы книгы” (1850) от братя Караминкови - предварителни бележки. - В: Рада и приятели. Сборник в чест на проф. д-р Радка Влахова. София: УИ Св. Климент Охридски, с. 275-284].

Nikolova 2021: Nikolova, N. „Yazik upotrebihme prost i vrazumitelen“. Pravopisni osobenosti na „Kniga za pisma“ (1850) ot bratya Karaminkovi. - Pod pechat v sp. Rodna rech, № 1 [Николова, Н. „Языкъ употрђбихме прость и вразумителенъ“. Правописни особености на „Книга за писма“ (1850) от братя Караминкови. - Под печат в сп. Родна реч, № 1].

Petkov 1848: Petkov, B. Shtogode za edno vseobshto Balgarsko Pravopisanie. Tsarigradski vestnik, A, 20, s. 3-4 [Петков, Б. Щогодђ за едно всеобщо Българско Правописаніе. - Цариградски въстникъ, А, 20, с. 3-4].

Stoyanov 1957: Stoyanov, M. Balgarska vazrozhdenska knizhnina. I. Sofia: Nauka i izkustvo [Стоянов, М. Българска възрожденска книжнина. I. София: Наука и изкуство].

Tsonchev 1929: Tsonchev, P. Iz stopanskoto minalo na Gabrovo. Sofia [Цончев, П. Из стопанското минало на Габрово. София].

Valchev 2008: Valchev, B. Vazrozhdenskite gramatiki na balgarskia ezik. Sofia: UI Sv. Kliment Ohridski [Вълчев, Б. Възрожденските граматики на българския език. София: УИ Св. Климент Охридски].

Vekov 2015: Vekov, M. Metrichnata sistema v Bulgaria. Metrichni reformi i metrologichna deynost XVIII-XX. Elektronna biblioteka po arhivistika i dokumentalistika. Sofia [Веков, М. Метричната система в България. 
Надка Николова. Кореспонденция, „на свой языкъ“...

Метрични реформи и метрологична дейност XVIII-XX. Електронна библиотека по архивистика и документалистика. София] $<$ https://electronic-library.org/books/Book_0057.html\#b0141 (status10.03.2021)>. 